\title{
The Impact of Cultural Similarity on Consumer Ethnocentrism Tendencies Toward Foreign Products
}

\author{
Eman Alshammari \\ School of Management, Swansea University, UK \\ Michael Williams \\ School of Management, Swansea University, UK
}

\begin{abstract}
Consumer ethnocentrism is found to be an important factor in making consumers adversely evaluate foreign products. This study is an attempt to improve understanding of consumer ethnocentrism and its influence on consumer attitude and purchase intention toward foreign products in an emergent market. It was also hypothesized that cultural similarity moderates the relationship between consumer ethnocentrism and purchase intention in which domestic products are not available. All but one of the hypotheses were accepted. Consumer ethnocentrism is found to have a strong influence on consumer attitude but does not significantly affect consumer purchase intention toward foreign products. Cultural similarity was found to have a significant moderating effect on the relationship between consumer ethnocentrism and purchase intention. This suggests that cultural similarity plays an important role for ethnocentric consumers in the evaluation of foreign products. Theoretical and managerial implications are discussed.
\end{abstract}

Keywords: Consumer Ethnocentrism; Cultural Similarity; Attitude; Purchase Intention

\section{INTRODUCTION}

In the era of globalization, consumers are being more exposed than ever before to a variety of foreign products from other countries. This leads to a substantial competition amongst international marketers to expand their businesses around the world. However, international marketers become more concerned to understand consumer attitudes toward foreign products before they make their market strategies. The marketing literature reveals mixed results of consumers' acceptance of foreign products, whereas some consumers viewed imported products as preferable. But other consumers have a negative attitude toward foreign products and thus purchase domestic products. This negative perception of foreign products can stem from consumer ethnocentrism. Consumer ethnocentrism plays a role in shaping consumers' buying behaviour and therefore can act as an obstacle to international trade (Deb \& Chaudhuri, 2014). It is generally agreed in the literature that ethnocentric consumers have a strong preference for domestic products (Dogi, 2015). However, other studies in developed countries suggest that ethnocentric consumers have a more favourable attitude toward products from countries that are viewed as culturally similar to their own home country in case products are not manufactured domestically (Watson \& Wright, 2000). Although most of the past studies have examined the influence of consumer ethnocentrism toward foreign products in which domestic products are available, this paper seeks to understand consumers' purchase intention toward foreign products alternatives in which domestic products are not available. This is important for marketers to make their strategic decisions about products and services in the global market.

This paper begins with a review of consumer ethnocentrism and the effect of country of origin. A number of hypotheses are then formulated, followed by methods used to test hypotheses, analytical results, and a conclusion with discussion and implications. 


\section{Consumer Ethnocentrism}

\section{LITERATURE REVIEW}

Consumer ethnocentrism may indicate a general tendency of consumers to reject foreign products regardless of product quality or price considerations (Siamagka \& Balabanis, 2015). Consumer ethnocentrism is derived from the general concept of ethnocentrism that was first introduced in socio-psychological literature. Sumner (1906, p.13) has defined ethnocentrism as the "view of things in which one's group is the centre of everything, and all others are scaled and rated with reference to it". In his book, he states his belief that each group has pride in their own group and the perception of other groups as being subordinate. According to Sumner, each group has feelings of pride and superiority but other groups are perceived as inferior from the host-group's point of view. Similarly, Siamagka and Balabanis (2015) use the notion of the "cognitive aspect" to explain how ethnocentric people understand the out-group being different from their own ethnic perspective. Importantly, they argue that this creates bias against foreign countries. This is in line with the views of Shimp and Sharma (1987) who showed how ethnocentrism is important to purchasing behaviour and that difference of views can be found about how a host country produces superior products while other countries produce inferior products. According to Shimp and Sharma (1987), consumer ethnocentrism is about the beliefs held by customers who see purchasing foreign products as immoral - that it can hurt the local economy and cause job losses while also being unpatriotic.

\section{The Country of Origin Effect (COO)}

In general, the country-of-origin effect suggests that consumers' perceptions and attitudes about foreign products and their attributes are influenced by the COO (Chryssochoidis et al., 2007; Soares, 2014). Since the 1960s, the country-of-origin effect has been found to be a significant research topic in the international marketing literature (Deb \& Chaudhuri, 2014; Rezvani et al., 2012). Despite several studies on COO effects having been conducted in different contexts, the subject is still recommended for further investigation (Sohail \& Opoku, 2016). The growth of international trade and the evolution of international consumer segments have increased interest in investigating the influence of COO on consumers' evaluations of foreign products (Fischer \& Zeugner-Roth, 2016). Researchers in marketing suggest that COO can strongly influence consumers' attitudes toward products originating from different countries (Sohail \& Opoku, 2016). According to Thøgersen et al. (2017), COO has an important role in shaping consumers' behavioural intention toward foreign products. Consumers tend to rely on COO cues when information about the product is not available [nc] and then use COO to predict the preference of the products that are produced in a certain country and whether they have certain desirable features (Shankarmahesh, 2006; Yim Wong, Polonsky, \& Garma, 2008).

The previous studies differ in their conclusions, with some indicating that the effect of COO on consumer evaluation of products and purchase intention were significant [nc] while others argued it is doubtful. Wang and Chen (2004) believe consumers from developed countries prefer to buy domestic products rather than foreign products while consumers from developing countries prefer to purchase foreign products from developed countries such as the UK, the USA and Japan (see also Hamin \& Elliott, 2006; Nadiri \& Tümer, 2010; Sohail, 2005). In comparison, Batra et al. (2000) found that $\mathrm{COO}$ has an effect on ethnocentric consumers toward non-local brands of different products categories among Indian consumers. In addition, New Zealand consumers' attitudes toward foreign products have also been investigated by Tong and Shergill (2007). They used different countries of origin, such as the USA, Japan, Germany and China, and found that COO was a significant factor that affected consumers' attitudes toward certain products. Hence, consumer perspectives and their evaluation of foreign or domestic products can be based on the quality of a specific product, the origin [nc] or both (Balabanis \& Diamantopoulos, 2004), again illustrating complexity. 
However, consumers may have a positive attitude toward a product from a specific country of origin [nc] but they resist purchase owing to feelings of patriotism and concerns about damage to the national economy (Shimp \& Sharma, 1987). Researchers in consumer ethnocentrism suggest that consumer ethnocentrism is one of the $\mathrm{COO}$ antecedents, explaining that $\mathrm{COO}$ has a mediating effect on the relationship between consumer ethnocentrism and product evaluations or preferences (Balabanis \& Siamagka, 2017; Shankarmahesh, 2006). The effect of consumer ethnocentrism and $\mathrm{COO}$ has been widely discussed from different perspectives, with some arguing that the influence of $\mathrm{COO}$ is significant to a consumer's views in product evaluation (Chryssochoidis et al., 2007; Deb \& Chaudhuri, 2014). Ethnocentric consumers use COO to differentiate between domestic products and foreign products when they make their purchases (Balabanis \& Siamagka, 2017). This indicates that the COO cue is important for ethnocentric consumers to reject the products made in different countries, but it seems not important for non-ethnocentric consumers to accept or reject a product, as they focused more on products attributes rather than COO (Chryssochoidis, et al., 2007; Thøgersen et al., 2017).

Researchers suggest that the availability of domestic products is important to measure consumer ethnocentric tendencies toward purchasing domestic or foreign products. Most of the previous studies investigated the impact of consumer ethnocentrism when domestic and foreign products are available (see Acharya \& Elliott, 2003; Altintaş \& Tokol, 2007; Balabanis \& Diamantopoulos, 2004; Bandara \& Miloslava, 2012; Fernández-Ferrín et al., 2015; Shimp et al., 1995; Shimp \& Sharma, 1987). However, consumer ethnocentrism tendency is also activated when domestic products are not available. Ethnocentric consumers will have no choice but to buy foreign products (Balabanis \& Diamantopoulos, 2004; Moon \& Jain, 2002; Watson \& Wright, 2000). This notion was discussed by Sharma et al. (1995), who suggested that ethnocentric consumers may select product categories from countries based on cultural similarity. The notion is that ethnocentric consumers strongly prefer buying domestic products over foreign products but when domestic products are not available, they tend to purchase foreign products from culturally similar categories to those of their home country. It seems that product category and availability lead to a consideration of why country of origin (COO) is important for ethnocentric consumers. The next section discusses the importance of cultural similarity to consumer ethnocentrism.

\section{The Role of Cultural Similarity}

Past studies have discussed the impact of products from culturally similar countries on consumers' evaluations toward purchasing foreign products (Balabanis \& Siamagka, 2017). Ma, Wang and Hao (2012) examined cultural similarity effects on consumers' products judgment and their willingness to purchase foreign products. They used Hofstede's model of cultural difference to measure cultural similarities between Taiwan, as the home country, and the USA, China and Japan as foreign countries. They chose these countries because they were different from the origin country, Taiwan. China is culturally similar in this regard because of historical reasons, such as the fact that the majority of the population in Taiwan are Chinese and [nc] therefore, share a similar cultural background and speak the same language. On the other hand, Taiwan and Japan are culturally closer than the USA because they share a similar Asian culture and their geographical location is closer (Ma et al., 2012). The findings showed that foreign products from a culturally similar country were positively correlated with consumer evaluation of, and willingness to buy, the products. Cultural similarity is an important factor and has a significant impact on ethnocentrism tendency.

Researchers have attempted to investigate the impact of consumer ethnocentrism on consumer purchasing behaviour toward foreign products when domestic products are not 
available. According to Shimp et al. (1995), the impact of consumer ethnocentrism and consumer attitude toward foreign products may be conditioned by the lack of availability of domestic alternatives. Empirical evidence shows that cultural similarity weakens the adverse effects of consumer ethnocentrism on foreign products (Evanschitzky et al., 2008; Ma, Wang, \& Hao, 2012; Watson \& Wright, 2000). For example, Watson and Wright (2000) have examined the moderating effect of cultural similarity on the relationship between consumer ethnocentrism and willingness to buy foreign products in New Zealand. Their findings showed that ethnocentric consumers positively evaluated products from culturally similar nations because they were familiar with the countries concerned and geographically closer than other dissimilar countries. Watson and Wright (2000) conclude that cultural similarity plays an important role in evaluating foreign products by ethnocentric consumers.

In contrast, other studies found that cultural similarity did not mitigate the negative effects of consumer ethnocentrism on consumer purchase intention toward foreign products (Balabanis et al., 2001; Balabanis \& Siamagka, 2017). The research by Ramadania, Gunawan and Rustam (2015) examined the impact of cultural similarity on the relationship between consumer ethnocentrism and attitudes toward Malaysian products in Indonesia[n?]. The findings showed that consumer ethnocentrism has a negative impact on consumer attitudes toward purchasing foreign products, and cultural similarity did not play a role to reduce the negative impact of consumer ethnocentrism toward purchasing foreign products. Similarly, Šmaižienè and Vaitkienè (2015) found that ethnocentric consumers did not prefer to purchase foreign-made dietary supplements from culturally similar countries to Lithuania, regardless of the quality of foreign products.

\section{HYPOTHESIS DEVELOPMENT}

\section{Consumer Ethnocentrism and Attitude}

Based on the concept of consumer ethnocentrism, ethnocentric consumers have a strongly favourable attitude toward local products rather than foreign products. Previous studies found that consumer ethnocentrism negatively affects attitudes toward foreign products (Batra et al., 2000; Giang \& Khoi, 2015; Hamin \& Elliott, 2006; He \& Wang, 2015; Nijssen et al., 1999; Shankarmahesh, 2006; Sharma et al., 1995; Shimp \& Sharma, 1987; Tsai et al., 2013; Watson \& Wright, 2000). This indicates that consumers have positive feelings toward domestic products and a bias against foreign products. Previous studies have found statistical evidence for a direct negative link between consumer ethnocentrism and attitude toward foreign products (Chowdhury, 2013; He \& Wang, 2015; Jamil et al., 2010; Tsai et al., 2013). Based on previous findings, it can be expected that highly ethnocentric consumers will reject foreign products, whereas a consumer with lower ethnocentric feelings is more likely to have a positive attitude toward foreign products. Thus, the following hypothesis is put forward.

H1: There is a negative relationship between consumer ethnocentrism and attitude toward foreign products

\section{Consumer Ethnocentrism and Intention}

Intention" indicates a willingness or readiness to engage in purchasing behaviour (Paul et al., 2016) and is an important aspect that can determine future behaviours (Ajzen, 2014; Alam \& Sayuti, 2011). From a marketing standpoint, ethnocentric tendency is a consumer's positive perception of domestically-made products that, in turn, create a preference for their own local products (He \& Wang, 2015; Maina et al., 2015; Nguyen et al., 2008; Sharma et al., 1995; Šmaižienè \& Vaitkienè, 2014; Tsai et al., 2013). Previous studies related to the purchase of domestic and foreign products have found that when attitude towards and intention to purchase are positive, the consumer is highly likely to purchase that product (Giang \& Khoi, 2015). Empirical evidence in this area found that ethnocentric consumers demonstrate a 
negative attitude that, in turn, affects their intention to purchase foreign products (Sharma et al., 1995; Wang \& Chen, 2004; Giang \& Khoi, 2015; Kumar et al., 2009; He \& Wang, 2015; Josiassen et al, 2011). Thus, based on the previous findings in the literature, consumer ethnocentrism is negatively related to purchase intention toward foreign products. It is therefore proposed that:

H2: There is a negative relationship between consumer ethnocentrism and purchase intention toward foreign products.

\section{Attitude Toward Foreign Products}

Attitude is about an individual's approval or disapproval of a behaviour in question (Ajzen \& Fishbein, 1980). A positive attitude towards a behaviour will result in a strong intention to act out that specific behaviour (Ajzen, 2005; Ajzen \& Fishbein, 1980). Based on the theoretical models of buyer behaviour prediction, such as the theory of planned behaviour (TPB), behaviour is affected by intention as a direct predictor, with the latter influenced by attitude. Stronger positive attitudes toward foreign products will create a higher interest in and intention to purchase them (Shankarmahesh, 2006; Wang \& Chen, 2004). Prior studies provide evidence that consumer attitudes positively affect consumer intention toward foreign products (Batra et al., 2000; Deb \& Chaudhuri, 2014; Hamin \& Elliott, 2006, Nagashima, 1970; Nijssen et al., 1999; Sharma et al., 1995). It has been found that consumers in developing countries view foreign products more favourably than domestic ones (Bhuian, 1997; Sohail, 2005). Based on these findings, the following hypothesis is put forward.

H3: There is a positive relationship between consumer attitude and purchase intention.

\section{Moderating Effect of Cultural Similarity}

Social psychology theories, such as social-identity theory (Tajfel, 2010), describe the effect of in-group favouritism and out-group prejudice. This notion can be traced back to the concept of ethnocentrism developed by Sumner (Ma et al., 2012). Sumner (1906) stated that other groups that share the same values, language or environment can be categorized as in-group. This becomes a concern to the international marketer seeking to understand consumers' attitude toward, and evaluation of, foreign products from similar cultures to that of the consumer's home country. According to Ma et al. (2012), consumers tend to accept foreign products that are made in similar countries to the host country. Prior studies found that cultural similarity has a moderating role regarding the relationship between consumer ethnocentrism and purchase intention (Shankarmahesh, 2006). There is empirical evidence (Bruning \& Saqib, 2013; Fenwick et al., 2003; Sharma et al., 1995; Watson \& Wright, 2000) which suggests that cultural similarity can reduce the effect of consumer ethnocentrism toward foreign product purchase intention. Watson and Wright (2000) examined the moderating effect of cultural similarity on the relationship between consumer ethnocentrism and consumers' evaluation and intention of purchasing foreign products in New Zealand. They also found that cultural similarity has a significant influence on ethnocentric consumerism. However, other studies found otherwise (Balabanis \& Diamantopoulos, 2004; Balabanis \& Siamagka, 2017). Based on the above discussion, it is assumed that a cultural similarity factor may weaken the effect of consumer ethnocentrism toward consumers' purchase intention toward foreign products in an emergent market. The following is therefore proposed:

H4: Cultural similarity has a moderating effect on the relationship between consumer ethnocentrism and purchase intention. 


\section{Data Collection}

\section{METHODOLOGY}

The data of this study were collected in Riyadh City, which is the capital city of the Kingdom of Saudi Arabia. Riyadh is a metropolitan city and people who live in this city came from different geographical regions of the country, therefore representing accurately the country's urban population. A convenience sampling method and snowball method were used to collect the information from consumers. These were distributed by using the self-administration method. A total of 407 respondents from a total of 702 completed questionnaires with a response rate of $57 \%$.

\section{Selection of Products}

Although several studies have examined consumer ethnocentrism and attitude toward high involvement products, researchers suggest the need to investigate the effect of consumer ethnocentrism toward low involvement product categories (Javalgi et al., 2005). The literature offered some suggestions that should be considered before choosing the products under investigation. According to Sharma et al. (1995), the selection of products should be those deemed necessary to consumers in their daily life. Hamin and Elliott (2006) stated that products should be selected based on daily consumption and should be sold in stores that are near to the potential respondents. To examine consumer ethnocentrism toward foreign products, selecting products should entail having at least one domestic product available (e.g. in this case Saudi Arabian product) and foreign alternative products (Watson \& Wright, 2000). Although past studies used different products categories, few studies have investigated the effect of consumer ethnocentrism focusing on food products (Chryssochoidis et al., 2007). Based on the existing literature, this study selected low involvement, frequently-purchased and daily consumption products categories to understand the effect of consumer ethnocentrism on decisions to purchase these types of foreign products in the context of Saudi Arabia. These products are fruit, vegetables, cheese and bottled water.

\section{Selection of Countries}

The countries were selected based on the review of the literature on consumer ethnocentrism. Previous research has selected foreign countries based on main exporters to the home country (Chryssochoidis et al., 2007), economically developed countries (Balabanis \& Diamantopoulos, 2004) or neighbouring countries with geographical proximity (Nijssen \& Douglas, 2004; Ramadania et al., 2015). For this research, the countries were chosen based on details of exports of large amounts of products to the Saudi market that include vegetables, fruits, cheese and bottled water. Some of these countries are neighbours and some, such as the USA, the UK, India, Lebanon and Turkey, can be classified as main trading importers to Saudi Arabian markets. However, because this research aims to understand consumer ethnocentrism regarding purchasing intention when the product is made in culturally similar countries, the main importers of the four products were tested by the CDI index developed by Kogut and Singh (1988) in order to identify the most culturally similar countries to Saudi Arabia. CDI calculated based on Hofested's (1980) six cultural dimensions, and computed as follows:

$$
C D_{j}={ }^{4}\left\{\left(I_{i j} \quad I_{i s}\right)^{2} / V_{i}\right\} / 6
$$

Where $I_{i j}$ is the index for ith cultural dimension of the country j, while $I_{\text {is }}$ is the index of Saudi Arabia on the dimension. $V_{i}$ is the variance of index $i$, and $s$ refers to Saudi Arabia. Lastly, the number six represents the number of the dimensions - namely power distance, individualism versus collectivism, masculinity versus femininity, uncertainty avoidance index, long-term 
orientation and indulgence. However, countries should be selected before conducting CDI to identify the cultural similarity of each country to the home country. Countries that are similar to the home country should have a low CDI score while dissimilar countries have a high CDI score. The countries chosen for this study, along with each product category and their CDI scores, are listed below, in Table 1. Countries with lower scores, such as Jordan, Lebanon and Turkey, are categorized as being culturally similar to Saudi Arabia.

Table 1 Cultural Distance Index Results

\begin{tabular}{|c|c|c|}
\hline Products Type & Countries & CD Scores to Saudi Arabia \\
\hline \multirow{6}{*}{ Vegetables } & Jordan & 0.538063286 \\
\hline & Lebanon & 0.970280999 \\
\hline & Egypt & 1.175197164 \\
\hline & India & 1.315838105 \\
\hline & USA & 2.642788547 \\
\hline & The Netherlands & 3.645102188 \\
\hline \multirow{6}{*}{ Fruits } & Jordan & 0.533784617 \\
\hline & Turkey & 0.434130189 \\
\hline & Lebanon & 1.371684938 \\
\hline & France & 1.636322565 \\
\hline & South Africa & 1.818007565 \\
\hline & USA & 3.270783239 \\
\hline \multirow{6}{*}{ Bottled Water } & Turkey & 0.674359834 \\
\hline & Lebanon & 0.864211925 \\
\hline & Egypt & 1.442877525 \\
\hline & France & 1.480759561 \\
\hline & Switzerland & 2.516291474 \\
\hline & UK & 3.271354593 \\
\hline \multirow{6}{*}{ Cheese } & Turkey & 0.922268163 \\
\hline & Jordan & 0.986326108 \\
\hline & Egypt & 1.823324801 \\
\hline & France & 1.696821012 \\
\hline & USA & 2.432224808 \\
\hline & New Zealand & 2.784012254 \\
\hline
\end{tabular}

\section{Measures}

A structured questionnaire was used to collect the data for this study. This study adopted the validated scale from previous studies to examine the constructs under study with seven-point Likert scale. For consumer ethnocentrism, it has been measured by eight items of the CETSACLE, developed by Shimp and Sharma (1987). Three items were used to measure attitude and intention adopted from the well-known theory of TPB by Ajzen (1985). A sevenpoint Likert scale, behavioural intention item was used to measure consumer purchase intention toward each product from each country to examine the moderating effect of cultural similarity on the relationship between consumer ethnocentrism and purchase intention toward foreign products.

\section{The Sample}

\section{ANALYSIS AND RESULTS}

Participants were asked to provide their personal characteristics of age, gender, income [nc] and education. Of 407 participants, $46.9 \%$ were male and $53.1 \%$ were males. Approximately 44\% were between 25 and 34 years old. Almost 56\% had a bachelor's degree. Income level was varied among participants, with the highest percentage being $21 \%$ with an income between SR 9000 and SR 12000 (about US\$ 2400 to 3200 monthly), which is higher than the monthly income average (average $=$ SR 9000). 


\section{Hypothesis Testing}

In order to evaluate the measurement and structural model, partial least square structural equation modelling (PLS-SEM) through SmartPLS 3.3 software was used (Hair et al., 2016). The assessment of measurement model initially focuses on evaluating the indicator reliability, internal consistency reliability, convergent validity and discriminant validity (Hair et al., 2016). All scales are robust in terms of their reliability, since the Cronbach's alpha of each construct exceeded the threshold value of 0.70. In addition, as prior researchers suggested that composite reliability is a more appropriate technique for PLS-SEM than Cronbach's alpha (Amaro \& Duarte, 2015; Hair et al., 2016), it ranged from 0.81 to 0.93 , which is higher than the cut-off point of 0.70 suggested by Hair et al. (2016). Finally, most of the indicator loadings are above that threshold value of 0.60 . To ensure the convergent validity, the average variance extracted (AVE) of each construct should be calculated. The validity of all constructs is achieved, since the AVE values exceeded the recommended threshold value of 0.50 (Sarstedt et al., 2014). For assessing discriminate validity, the Heterotrait-Monotrait ratio (HTMT) is one of the PLS-SEM tests that aims to ensure that all the constructs are distinct and related to their own measures and not to other constructs (Carter \& Maher, 2015). The results support that all the constructs are distinct and lower than the threshold value of 1 suggested by Hair et al. (2016). Therefore, the measurement model results provide support for the overall quality of the constructs' measures.

Since the measurement model provides evidence of the reliability and validity of the measures, the structural model is for assessing the hypothesized relationships among the constructs in the conceptual model (Hair et al., 2016). According to Carter and Maher (2015), the standardized path coefficients and significance levels allow researchers to test the proposed hypotheses. The first hypothesis $\mathrm{H} 1$ hypothesized that consumer ethnocentrism has a negative effect on consumer attitude towards foreign products. This was supported $(\beta=-0.585, \mathrm{p}<$ .001), and is consistent with previous studies (Chowdhury, 2013; He \& Wang, 2015; Jamil et al., 2010; Javalgi et al., 2005; Qing et al., 2012; Tsai et al., 2013; Wanninayake \& Chovancová, 2012; Watson \&Wright, 2000). However, consumer ethnocentrism was found to be a significant predictor for attitude but not for purchase intention toward foreign products in this study (H2) ( $\beta=-0.010, \mathrm{p}=.378$ ). This finding is consistent with other studies (Ding, 2016; Good \& Huddleston, 1995; Yim Wong et al., 2008). Consumer ethnocentrism appears to be independent from consumer purchase intention and is not important for Saudi consumers when they purchase foreign products. H3 hypothesized that consumer attitude has a positive effect on purchase intention toward foreign products. The results provide support for this hypothesis, giving evidence that consumer attitude has a significant effect on intention toward foreign products $(\beta=0.624, p<.001)$. This result is in line with previous research that has examined the relationship between attitude and purchase intention (Javalgi et al., 2005; Jin \& Kang, 2011; Makanyeza \& Du Toit, 2017; Son et al., 2013; Watson \& Wright, 2000). Lastly, H4 hypothesized that cultural similarity moderates the relationship between consumer ethnocentrism and purchase intention toward foreign products. The results here show that cultural similarity has a significantly moderating effect on the relationship between consumer ethnocentrism and purchase intention $(\beta=-0.0582, \mathrm{p}<.01)$, which is consistent with Ma et al. (2012), Sharma et al. (1995) and Watson and Wright (2000).

\section{DISCUSSION AND IMPLICATIONS}

In this study, the main object was to understand the influence of consumer ethnocentrism and purchase intention toward foreign products in which domestic products alternatives are not available. The study found that consumer ethnocentrism has a significant negative impact on consumers' attitude toward foreign products but no effect was found on consumer purchase intention. This means that consumer ethnocentrism tendencies did not automatically translate 
into bias for foreign products. This may be due to Saudi consumers already having been exposed to many foreign products and Western hypermarkets, which, in turn, makes different foreign products more familiar to consumers. Another explanation is that consumers may consider other product attributes when they make their purchase. Bhuian (1997) and Sohail (2005) found that Saudi consumers consider quality and price when they make their purchase, considering foreign products to be of better quality and greater novelty than domestic goods, even when those consumers have ethnocentric tendencies. In addition, this study found that consumer attitude is a strong predictor of purchase intention. Saudi consumers showed a preference for buying foreign products. This study confirms the results of previous studies (Evanschitzky et al., 2008; Shankarmahesh, 2006; Watson \& Wright, 2000) that ethnocentric consumers tend to buy foreign products from culturally similar countries once domestic products are not available. Ethnocentric Saudi consumers have more preference toward food products imported from countries such as Jordan and Lebanon, rather than from culturally dissimilar countries such as the USA and The Netherlands.

The findings of this study suggest that consumer ethnocentrism does not translate into biased feeling against foreign products - evidence that, interestingly, is not consistent with that put forward by Josiassen et al. (2011), who argued that all domestic consumers are ethnocentric. This may be a positive sign for international marketers who intend to expand their businesses into developing markets. Also, it may not be necessary for marketers to pay particular attention to the influence of consumer ethnocentrism when planning marketing strategies for their businesses in developing countries. International marketers who intend to expand their business in other countries need to consider the effect of cultural similarity on consumer behaviour. They may need to decrease the emphasis on $\mathrm{COO}$ and effectively promote attributes and benefits of their products.

\section{References}

Acharya, C., \& Elliott, G. (2003). Consumer Ethnocentrism, perceived product quality and Choice-An empirical investigation. Journal of International Consumer Marketing, 15(4), 87-115. doi: 10.1300/j046v15n04_05

Ajzen, I. (1985). From Intentions to Actions: A Theory of Planned Behavior: Berlin, Heidelberg: Springer.

Ajzen, I. (2005). Attitudes, personality and behavior ( $2^{\text {nd }}$ ed.). Maidenhead: Open University Press.

Ajzen, I. (2014). The theory of planned behaviour is alive and well, and not ready to retire: a commentary on Sniehotta, Presseau, and Araújo-Soares. Health Psychology Review, 9(2), 1-7.

Ajzen, I., \& Fishbein, M. (1980). Understanding attitudes and predicting social behavior: Illustration of applied social research. Englewood Cliffs, New Jersey: Prentice-Hall c.1980.

Altintaș, M., \& Tokol, T. (2007). Cultural openness and consumer ethnocentrism: An empirical analysis of Turkish consumers. Marketing Intelligence \& Planning.

Balabanis, G., \& Diamantopoulos, A. (2004). Domestic country bias, country-of-origin effects, and consumer Ethnocentrism: A multidimensional unfolding approach. Journal of the Academy of Marketing Science, 32(1), 80-95. doi: $10.1177 / 0092070303257644$

Balabanis, G., Diamantopoulos, A., Mueller, R. D., \& Melewar, T. C. (2001). The impact of nationalism, patriotism and internationalism on consumer Ethnocentric tendencies. Journal of International Business Studies, 32(1), 157175. doi: $10.1057 /$ palgrave.jibs.8490943

Balabanis, G., \& Siamagka, N.-T. (2017). Inconsistencies in the behavioural effects of consumer ethnocentrism: the role of brand, product category and country of origin. International Marketing Review, 34(2), 166-182.

Bandara, W., \& Miloslava, C. (2012). Consumer Ethnocentrism and attitudes towards foreign beer brands: With evidence from Zlin region in the Czech Republic. Journal of Competitiveness, 4(2), 3-19. doi:

10.7441/joc.2012.02.01 
Batra, R., Ramaswamy, V., Alden, D., Steenkamp, J., \& Ramachander, S. (2000). Effects of brand local and Nonlocal origin on consumer attitudes in developing countries. Journal of Consumer Psychology, 9(2), 83-95. doi: 10.1207/s15327663jcp0902_3

Bhuian, S. N. (1997). Marketing cues and perceived quality: Perceptions of Saudi consumers toward products of the U.S., Japan, Germany, Italy, U.K. And France. Journal of Quality Management, 2(2), 217-234. doi: 10.1016/s1084-8568(97)90004-3

Bruning, E., \& Saqib, N. U. (2013). Cultural similarity and national bias: An assessment in an international service context. Journal of Global Marketing, 26(1), 41-56. doi: 10.1080/08911762.2013.779407

Carter, L., \& Maher, A. (2015). Consumer Perceptions of Foreign Goods: Modeling the Path from Evaluation to Purchase. Journal of Marketing Development and Competitiveness, 9(1), 32-49.

Chowdhury, T. A. (2013). Understanding consumer Ethnocentrism in developing countries: Case Bangladesh. Journal of Global Marketing, 26(4), 224-236. doi: 10.1080/08911762.2013.814821

Chryssochoidis, G., Krystallis, A., \& Perreas, P. (2007). Ethnocentric beliefs and country-of-origin (CO0) effect. European Journal of Marketing, 41(11/12), 1518-1544. doi: 10.1108/03090560710821288

Deb, M., \& Chaudhuri, H. R. (2014). Impact of firm's reputation and ethnocentrism on attitude towards foreign products. Marketing Intelligence \& Planning, 32(5), 646-664. doi: 10.1108/mip-04-2013-0070

Ding, Q. S. (2016). Ours are always the best? A study of consumer ethnocentrism amongst urban adult Chinese consumers.

In: 4th International Conference on Contemporary Marketing, Issues, 24th June 2016, Heraklion, Greece.

Evanschitzky, H., Wangenheim, F., Woisetschläger, D., \& Blut, M. (2008). Consumer ethnocentrism in the German market. International Marketing Review, 25(1), 7-32. doi: 10.1108/02651330810851863

Fernández-Ferrín, P., Bande-Vilela, B., Klein, J. G., \& del Río-Araújo, M. L. (2015). Consumer ethnocentrism and consumer animosity: Antecedents and consequences. International Journal of Emerging Markets, 10(1), 73-88. doi: 10.1108/ijoem-11-2011-0102

Fischer, P., \& Zeugner-Roth, K. (2016). Disentangling country-of-origin effects: The interplay of product ethnicity, national identity, and consumer ethnocentrism. Journal of Research in Marketing, 28 (2), 189-204. doi: 10.1007/s11002-016-9400-7

Giang, T., \& Khoi, N. D. (2015). The Impact of Consumer Animosity and Consumer Ethnocentrism on Intention to Purchase Foreign Products: The Case of Chinese Branded Household Appliances in Vietnam Market. Journal of Economics and Behavioral Studies, 7(4), 22-36.

Good, L. K., \& Huddleston, P. (1995). Ethnocentrism of polish and Russian consumers: Are feelings and intentions related [?\} International Marketing Review, 12(5), 35-48. doi: 10.1108/02651339510103047

Goodhue, D., Lewis, W., \& Thompson, R. (2006). PLS, small sample size, and statistical power in MIS research. Paper presented at the System Sciences, 2006. HICSS'06. Proceedings of the 39th Annual Hawaii International Conference on.?

Hair, J., Black, W., Babin, B., \& Anderson, R. (2013). Multivariate data analysis (7th ed.). UK: Pearson.

Hair, J. F., Hair, J., Money, A. H., Samouel, P., \& M, A. H. (2003). Essentials of business research methods (2nd ed.). United States: John Wiley and Sons (WIE).

Hair, J. F., Hult, G. T. M., Ringle, C., \& Sarstedt, M. (2016). A Primer on Partial Least Squares Structural Equation Modeling (PLS-SEM) (2 $2^{\text {nd }}$ ed.). USA: Sage.

Hair , J. F., Joseph, F., Sarstedt, M., Ringle, C., M., \& Gudergan, S., P. (2017). Advanced Issues in Partial Least Squares Structural Equation Modeling. USA: Sage.

Hair, J. F., Ringle, C. M., \& Sarstedt, M. (2011). PLS-SEM: Indeed a silver bullet. Journal of Marketing theory and Practice, 19(2), 139-152.

Hamin, \& Elliott, G. (2006). A less-developed country perspective of consumer ethnocentrism and "country of origin" effects: Indonesian evidence. Asia Pacific Journal of Marketing and Logistics, 18(2), 79-92. doi: 10.1108/13555850610658246

He, J., \& Wang, C. L. (2015). Cultural identity and consumer ethnocentrism impacts on preference and purchase of domestic versus import brands: An empirical study in china. Journal of Business Research, 68(6), 1225-1233. doi: 10.1016/j.jbusres.2014.11.017 
Henseler, J., Ringle, C. M., \& Sarstedt, M. (2015). A new criterion for assessing discriminant validity in variancebased structural equation modeling. Journal of the Academy of Marketing Science, 43(1), 115-135.

Henseler, J., Ringle, C. M., \& Sarstedt, M. (2016). Testing measurement invariance of composites using partial least squares. International Marketing Review, 33(3), 405-431.

Henseler, J., Ringle, C. M., \& Sinkovics, R. R. (2009). The use of partial least squares path modeling in international marketing. New challenges to international marketing, 20, 277-319

Jamil, B., Siti Normah Awang, T., Aryaty, A., \& Maisarah, A. (2010). local vs. foreign products: are Malaysians ethnocentric. Journal of Marketing Management 9 (3), 6-23.

Javalgi, R. G., Khare, V. P., Gross, A. C., \& Scherer, R. F. (2005). An application of the consumer ethnocentrism model to french consumers. International

Josiassen, A., Assaf, A. G., \& Karpen, I. O. (2011). Consumer ethnocentrism and willingness to buy. International Marketing Review, 28(6), 627-646. doi: 10.1108/02651331111181448

Kumar, A., Lee, H.-J., \& Kim, Y.-K. (2009). Indian consumers' purchase intention toward a United States versus local brand. Journal of Business Research, 62(5), 521-527. doi: 10.1016/j.jbusres.2008.06.018

Lu Wang, C., \& Xiong Chen, Z. (2004). Consumer ethnocentrism and willingness to buy domestic products in a developing country setting: testing moderating effects. Journal of Consumer Marketing, 21(6), 391-400.

Ma, J., Wang, S., \& Hao, W. (2012). Does cultural similarity matter? Extending the animosity model from a new perspective. Journal of Consumer Marketing, 29(5), 319-332. doi: 10.1108/07363761211247442

Moon, B., \& Jain, S. (2002). Consumer processing of foreign advertisements: Roles of country-of-origin perceptions, consumer ethnocentrism, and country attitude. International Business Review, 11(2), 117-138. doi: 10.1016/s0969-5931(01)00052-x

Nadiri, H., \& Tümer, M. (2010). Influence of ethnocentrism on consumers' intention to buy domestically produced goods: An empirical study in north Cyprus. Journal of Business Economics and Management, 11(3), 444-461. doi: 10.3846/jbem.2010.22

Nagashima, A. (1970). A comparison of Japanese and U. S. Attitudes toward foreign products. Journal of Marketing, 34(1), 68. doi: 10.2307/1250298

Nguyen, T. \& Barrett, N. (2008). Consumer ethnocentrism, cultural sensitivity, and intention to purchase local products-evidence from Vietnam. Journal of Consumer Behaviour, 7(1), 88-100. doi: 10.1002/cb.238

Nguyen, T. (2017). Consumer Ethnocentrism, Country of Origin, Product Evaluation and Purchase Intention for Foreign Apparel Brands: the Study of Vietnam (Master dissertation). Aalto University, Finland.

Nijssen, E., Douglas, S., \& Bressers, P. (1999). Attitude toward the purchase of foreign products: Extending the model. Academy of Marketing, AMA Global Marketing SIG Joint Conference.

Nijssen, E. J., \& Douglas, S. P. (2004). Examining the animosity model in a country with a high level of foreign trade. International Journal of Research in Marketing, 21(1), 23-38. doi: 10.1016/j.ijresmar.2003.05.001

Qing, P., Lobo, A., \& Chongguang, L. (2012). The impact of lifestyle and ethnocentrism on consumers' purchase intentions of fresh fruit in China. Journal of Consumer Marketing, 29(1), 43-51.

Ramadania, Gunawan, S., \& Rustam, M. (2015). Cultural similarity, consumer Ethnocentrism and product necessity in evaluation of Malaysian products: Indonesian consumer perspective. Procedia - Social and Behavioral Sciences, 211, 533-540. doi: 10.1016/j.sbspro.2015.11.071

Rezvani, S., Javadian Dehkordi, G., Sabbir Rahman, M., Fouladivanda, F., Habibi, M., \& Eghtebasi, S. (2012). A conceptual study on the country of origin effect on consumer purchase intention. Asian Social Science, 8(12) doi: $10.5539 /$ ass.v8n12p205

Sarstedt, M., Henseler, J., \& Ringle, C. M. (2011). Multigroup analysis in partial least squares (PLS) path modeling: Alternative methods and empirical results Measurement and research methods in international marketing (pp. 195-218): Emerald Group Publishing Limited.

Sarstedt, M., Ringle, C. M., Smith, D., Reams, R., \& Hair, J. F. (2014). Partial least squares structural equation modeling (PLS-SEM): A useful tool for family business researchers. Journal of Family Business Strategy, 5(1), 105115.

Shankarmahesh, M., Ford, J., \& LaTour, M. (2003). Cultural Dimensions of Switching Behavior in ImporterExporter Relationships. Academy of Marketing Science Review, 3(6), 1-17. 
Shankarmahesh, M. N. (2006). Consumer ethnocentrism: An integrative review of its antecedents and consequences. International Marketing Review, 23(2), 146-172. doi: 10.1108/02651330610660065

Sharma, P. (2014). Consumer ethnocentrism: Reconceptualization and cross-cultural validation. Journal of International Business Studies, 46(3), 381-389. doi: 10.1057/jibs.2014.42

Sharma, S., Shimp, T., \& Shin, J. (1995). Consumer Ethnocentrism: A test of antecedents and Moderators. Journal of the Academy of Marketing Science, 23(1), 26-37. doi: 10.1177/0092070395231004

Siamagka, N.-T., \& Balabanis, G. (2015). Revisiting consumer Ethnocentrism: Review, reconceptualization, and empirical testing. Journal of International Marketing, 23(3), 66-86. doi: 10.1509/jim.15.0085

Šmaižienè, I., \& Vaitkienè, R. (2015). Consumer Ethnocentrism and attitudes towards the domestic and foreignmade dietary supplements (the case of Lithuanian market). Economics and Business, 26, 88. doi:

$10.7250 /$ eb.2014.025

Soares, A. M., Farhangmehr, M., \& Shoham, A. (2007). Hofstede's dimensions of culture in international marketing studies. Journal of Business Research, 60(3), 277-284. doi: 10.1016/j.jbusres.2006.10.018

Sohail, M. S., \& Opoku, R. A. (2016). Applying the Animosity Model in Foreign Product Purchases: Evidence from an Emerging Nation. Journal of International Consumer Marketing, 28(2), 121-134.

Sohail, S. (2005). Saudi Consumers' Perceptions of Foreign Products. Journal of International Business and Entrepreneurship, 11(1), 93-106

Sumner, W. (1906). Folkways - A study of the sociological importance of usages, manners, customs, mores and morals. Boston: Ginn and Company.

Tajfel, H. (Ed.). (2010). Social Identity and Intergroup Relations. Retrieved from

https://books.google.co.uk/books?hl=en\&lr=\&id=q0wFY3Dcu1MC\&oi=fnd\&pg=PR11\&dq=social+identity+and+i ntergroup+relations\&ots=qvqnDbapNt\&sig=JxdUYdE9G5EzxlmOlv9qzWffw3k\#v=onepage\&q=social\%20identity $\% 20$ and\%20intergroup\%20relations\&f=false

Thøgersen, J., Pedersen, S., Paternoga, M., Schwendel, E., \& Aschemann-Witzel, J. (2017). How important is country-of-origin for organic food consumers? A review of the literature and suggestions for future research. British Food Journal, 119(3), 542-557.

Tong, L. I. N., \& Shergill, G. (2007). New Zealand Consumers ' Attitudes towards Australian, United States, Japanese, German and Chinese Products and Marketing Practices. New Zealand Journal of Applied Business Research.

Tsai, W., Lee, W., \& Yoo, J. (2013). A cross-cultural study of consumer ethnocentrism in China, South Korea, and the United States. In American Academy of Advertising. Conference. Proceedings (Online), 46. American Academy of Advertising.

Wang, C., \& Chen, Z. (2004). Consumer ethnocentrism and willingness to buy domestic products in a developing country setting: Testing moderating effects. Journal of Consumer Marketing, 21(6), 391-400. doi: 10.1108/07363760410558663

Wanninayake, W., \& Chovancová, M. (2012). Consumer ethnocentrism and attitudes towards foreign beer brands: With evidence from Zlin Region in the Czech Republic. Journal of Competitiveness, 4(2)

Watson, J. J., \& Wright, K. (2000). Consumer ethnocentrism and attitudes toward domestic and foreign products. European Journal of Marketing, 34(9), 1149-1166. doi: 10.1108/03090560010342520

Yim Wong, C., Polonsky, M. J., \& Garma, R. (2008). The impact of consumer ethnocentrism and country of origin sub-components for high involvement products on young Chinese consumers' product assessments. Asia Pacific journal of marketing and logistics, 20(4), 455-478.

Yim Wong, C., Polonsky, M. J., \& Garma, R. (2008). The impact of consumer ethnocentrism and country of origin sub-components for high involvement products on young Chinese consumers' product assessments. Asia Pacific Journal of Marketing and Logistics, 20(4), 455-478. doi: 10.1108/13555850810909759

Yoo, B., \& Donthu, N. (2005). The effect of personal cultural orientation on consumer ethnocentrism: Evaluations and behaviors of US consumers toward Japanese products. Journal of International Consumer Marketing, 18(1-2), 7-44.

Young, W., Hwang, K., McDonald, S., \& Oates, C. (2010). Sustainable consumption: Green consumer behaviour when purchasing products. Sustainable Development, 18(1), 20-31. doi: 10.1002/sd.394 
Zafer Erdogan, B., \& Uzkurt, C. (2010). Effects of ethnocentric tendency on consumers' perception of product attitudes for foreign and domestic products. Cross Cultural Management: An International Journal, 17(4), $393-406$. doi: 10.1108/13527601011086595

Zbib, I. J., Wooldridge, B. R., Ahmed, Z. U., \& Benlian, Y. (2010). Purchase of global shampoo brands and the impact of country of origin on Lebanese consumers. Journal of Product \& Brand Management, 19(4), 261-275. doi: 10.1108/10610421011059586

Zeugner-Roth, K., Žabkar, V., \& Diamantopoulos, A. (2015). Consumer ethnocentrism, national identity, and consumer cosmopolitanism as drivers of consumer behavior: A social identity theory perspective. Journal of international marketing, 23(2), 25-54.

Zhang, Y. (1996). Chinese consumers' evaluation of foreign products: The influence of culture, product types and product presentation format. European Journal of Marketing, 30(12), 50-68. doi: 10.1108/03090569610153309

Zhou, L., \& Wong, A. (2008). Exploring the influence of product conspicuousness and social compliance on purchasing motives of young Chinese consumers for foreign brands. Journal of Consumer Behaviour, 7(6), 470-483. doi: $10.1002 /$ cb.265 